\title{
Crumbs proteins control ciliogenesis and centrosome organization: what about the mechanism?
}

\author{
M Barthelemy-Requin ${ }^{1 *}$, JP Chauvin', CL Baron-Gaillard ${ }^{1}$, P Rashbass², D Massey-Harroche', A Le Bivic \\ From Cilia 2014 - Second International Conference \\ Paris, France. 18-21 November 2014
}

\section{Objective}

This project aims to identify the function of polarity protein complexes in the formation of the primary cilia. We focus specifically on the two apical complexes: the Crumbs (Crb/Pals-1/PATJ) and the PAR (Par3/Par6/ aPKC) complexes. In this study, we investigated the role of Crumbs in ciliogenesis.

\section{Methods}

The depletion of crumbs2 (Crb2) and/or crumbs3 (Crb3) via transient siRNA transfection in ARPE-19 cells (human pigmented retina epithelium) leads to strong inhibition of ciliogenesis which underscores the involvement of $\mathrm{Crb} 2$ and $\mathrm{Crb} 3$ in the formation of the primary cilia.

\section{Results}

Crb2 and Crb3 share many protein interactions and mechanisms of compensation could exist. However our data revealed the contrary since we showed that primary cilia formation requires a threshold level of both Crb2 and $\mathrm{Crb} 3$. To decipher the mechanism that underlies this requirement we have focused on $\mathrm{Crb2}$, which is predominantly expressed in ARPE-19 cells. Using both optical imaging and electron microscopy we showed that $\mathrm{Crb} 2$ is involved in cilia initiation but not cilia maintenance. Furthermore we uncovered that $\mathrm{Crb} 2$ acts at a very early stage of ciliogenesis, by affecting the localization of centriolar and peri-centriolar markers such as PCM-1.

'IBDM, Université Aix-Marseille, CNRS UMR 7288, Campus de Luminy, Case 907, Marseille, France

Full list of author information is available at the end of the article

\section{Conclusion}

Crb2 allows the efficient organization of the centrosome and associated proteins and the primary vesicle formation to promote ciliogenesis. Taken together, our data show that Crb2 is essential for the primary ciliogenesis by a still unknown mechanism.

\section{Authors' details \\ 'IBDM, Université Aix-Marseille, CNRS UMR 7288, Campus de Luminy, Case 907, Marseille, France. ${ }^{2}$ Department of Biomedical Sciences, University of} Sheffield, Sheffield, UK.

Published: 13 July 2015

doi:10.1186/2046-2530-4-S1-P23

Cite this article as: Barthelemy-Requin et al: Crumbs proteins control ciliogenesis and centrosome organization: what about the mechanism? Cilia 2015 4(Suppl 1):P23.
Submit your next manuscript to BioMed Central and take full advantage of:

- Convenient online submission

- Thorough peer review

- No space constraints or color figure charges

- Immediate publication on acceptance

- Inclusion in PubMed, CAS, Scopus and Google Scholar

- Research which is freely available for redistribution
() Biomed Central 